\title{
Ionic transporters in the root nodule of Medicago truncatula: membrane antiporters $\mathrm{Na}^{+} / \mathrm{H}^{+}$
}

Trifonova N.A., Korolyova M.I., Fedorova E.E.

K.A. Timiryazev Institute of Plant Physiology RAS, Moscow, Russia

E-mail: natali.flow@yandex.ru

Key message. In root nodules of Medicago truncatula subjected to salt stress the level of expression of $\mathrm{Na}^{+} / \mathrm{H}^{+}$antiporters NHX1 and NHX7 was estimated. The localization of NHX1 was studied by confocal and electron microscopy.

Keywords: rhizobial symbiosis, salt stress, cation/proton antiporter

Symbiosis is a system composed from two organisms: legume plant and the soil bacteria Rhizobia. Nodules are quite sensitive to $\mathrm{NaCl}$ in the soil. Based on the low salinity resistance of the nodule, it can be assumed that nodule cells containing bacteria have defects in maintaining the ionic balance. Since the sequestration of sodium ions is one of the most important attribute of salt tolerance in plants, we investigated the cation/proton antiporters that are involved in the sequestration of sodium: NHX1 and NHX7 (Bassil and Blumwald, 2014). In Arabidopsis thaliana, these transporters are localized in different membrane compartments: AtNHX7 on the cytoplasmic membrane, AtNHX5-6 on the endosomes, and AtNHX1-4 on the tonoplast. The level of expression was estimated in the nodules of Medicago truncatula, from the plants exposed to short-term (5 days) and long-term (30 days) salt stress. Was observer the dynamics of expression of antiporters $\mathrm{Na}^{+} / \mathrm{H}^{+} \mathrm{NHX} 1$ and $\mathrm{NHX} 7$ in root nodules depending on the duration of stress.

The localization of the $\mathrm{Na}^{+} / \mathrm{H}^{+} \mathrm{NHX} 1$ antiporter was studied by immunocytochemistry and confocal microscopy in root nodules of Medicago truncatula. Analysis of the localization of the $\mathrm{Na}^{+} / \mathrm{H}^{+}$antiporter $\mathrm{NHX} 1$ showed the signal over the tonoplast of noninfected and infected cells, the signal was also partially associated with aging symbiosomes.

This work was supported by the Russian Science Foundation (project № 19-04-00570A).

\section{Ионные транспортеры в корневом клубеньке Medicago truncatula: мембранные антипортеры $\mathrm{Na}^{+} / \mathrm{H}^{+}$} Трифорова Н.А., Королева М.И. Федорова Е.Э.

Федеральное государственное бюджетное учреждение науки Институт физиологии растений им. К.А. Тимирязева РАН, Москва, Россия

\begin{abstract}
Аннотация. Исследованы ионные антипортеры, участвующие в секвестрировании натрия NHX1 и NHХ7: динамика экспрессии при солевом стрессе и локализащия в инфицированных и неинфицированных клетках в клубеньках Medicago truncatula.
\end{abstract}

Ключевые слова: ризобиальный симбиоз, солевой стресс, катион/протон антипортер

Симбиоз - двухкомпонентная система, состоящая из растения и бактерии. Результатом взаимодействия этих двух организмов является новый орган - корневой клубенек, где создаются условия для восстановления азота воздуха, происходит симбиотическая азотфиксация. Клубеньки чувствительны к содержанию в почве $\mathrm{NaCl}$. На основании низкой устойчивости клубенька к засолению, можно предположить, что клетки клубеньков имеют дефекты в поддержании ионного баланса. Поскольку выведение ионов натрия - это один из важнейших признаков солеустойчивости у растений, мы исследовали катион/протонные антипортеры, которые участвуют в секвестрировании натрия: NHX1 и NHX7 (Bassil and Blumwald, 2014). У Arabidopsis thaliana мембранные антипортеры $\mathrm{Na}^{+} / \mathrm{H}^{+}$локализованы в разных мембранных компартментах: AtNHX7 на цитоплазматической мембране, AtNHX5-6 на эндосомах и AtNHX1-4 на тонопласте.

В клубеньках Medicago truncatula измерен уровень экспрессии методом qPCR при действии краткосрочного (5 дней) и долгосрочного (30 дней) солевого стресса. Отмечена динамика экспрессии антипортеров $\mathrm{Na}^{+} / \mathrm{H}^{+} \mathrm{NHX} 1$ и $\mathrm{NHX} 7$ в корневых клубеньках в зависимости от срока действия стресса. Также исследована локализация $\mathrm{Na}+\mathrm{H}+\mathrm{aHтипортера}$ NHX1 методами иммуноцитохимии и конфокальной микроскопии в клубеньках Medicago truncatula. Анализ локализации $\mathrm{Na}^{+} / \mathrm{H}^{+}$антипортера $\mathrm{NHX1}$ показал сигнал в неинфицированных и инфицированных клетках на тонопласте, также сигнал был частично связан со стареющими симбиосомами.

Работа поддержана Российским научным фондом (проект № 19-04-00570А).

Bassil E., Blumwald E. The ins and outs of intracellular ion homeostasis: NHX-type cation/ $\mathrm{H}^{+}$transporters //Current Opinion in Plant Biology. - 2014. - Vol. 22. - P. 1-6. 